disease sera, guinea pig normal serum, and botb ovine and human normal serum.

Although only eighteen tests were made, all gave positive results, thus demonstrating both the specificity of the test in this condition and the appearance of complement-fixing antibodies in sheep serum. A typical result (Protocol No. 270) is given herewith.

\begin{tabular}{|c|c|c|c|c|c|c|}
\hline Tube & Anti- & Se- & Sal- & Com- & Red & Minutes reading \\
\hline & gen & rum & ine & $\begin{array}{c}\text { ple- } \\
\text { ment }\end{array}$ & cells & 10 \\
\hline $\begin{array}{l}1 \\
2\end{array}$ & $\begin{array}{l}0 \cdot 25 \\
0 \cdot 25\end{array}$ & $\begin{array}{l}0 \cdot 05 \\
0 \cdot 05\end{array}$ & $\begin{array}{l}0 \cdot 25 \\
0 \cdot 25\end{array}$ & $\begin{array}{l}0.25 \\
0.25\end{array}$ & $\begin{array}{l}0.5 \\
0.5\end{array}$ & $\begin{array}{l}++ \\
++\end{array}$ \\
\hline 3 & $0 \cdot 25$ & 0.05 & $0 \cdot 25$ & $0 \cdot 25$ & 0.5 & ; \\
\hline
\end{tabular}

Further experiments with regard to its specificity will be published in due course.

Aber A. Rottgardt

Hetctor G. Aramburu

Alfredo J. Garcfa Pirazzi

Instituto Nacional de la Fiebre Aftosa,

Buenos Aires.

May 20.

${ }^{1}$ Aramburu, H. G., Rev. Soc. Med. Vet. Bs. As. (Julio-Septiembre, 1947).

\section{The 'Oral Placode' in Certain Selachii and its Bearing on the Origin of the Vertebrate Mouth}

IN the course of a study of the early development of the sensory placodes of the head region in some eartilaginous fishes from the Red Sea, namely, Carcharinus melanopterus (Quoy and Gaimard), Rhynchobatus djiddensis (Bloch and Scheider) and Rhino. batus halaui (Müller and Henle), it was found that in the embryos of length 5-10 mm., the epidermis is generally thickened on either side of the roof of the mouth invagination and in the neighbourhood of the hypophysis (see drawing). This ectodermal

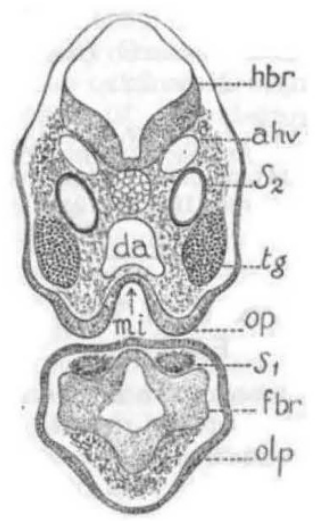

Transverse section through the mouth region of a $9 \cdot 5-\mathrm{mm}$. embryo of Rhynchobatus djiddensis illustrating the relation of the oral placode and the mouth

$a h v$, anterior head vein; $d a$, dorsal aorta; $f b r$, fore-brain ; $h b r$, hind-brain; $m i$, mouth invagination; olp, olfactory placode; $S_{1}$, flrst head somite (Platts' mass); $S_{2}$, second head somite; $\mathrm{tg}$, trigeminal gangiion

thickening is of the same structure as the epibranchial placodes which, in these embryonic stages, are situated at the dorsal edges of the corresponding branchial slits. In view of its particular situation over the mouth, it should be regarded as homonymous with these epibranchial placodes and as belonging to them. The structure in question should then have the same relation with the oral slit as the epibranchial placodes have with the spiracle and the following gill-slits. The term 'oral placode' was suggested for this structure, which is thus intexpreted as providing an interesting confirmation and adding further evidence to Dohrn's ${ }^{1}$ well-known and much discussed $^{2}$ theory considering the mouth of vertebrates as derived from a pair of anterior coalesced gill-slits.

Details of this work will be published elsewhere.

M. A. MrLouk

Department of Zoology,

Faculty of Science,

Fouad I University,

Abbassia, Cairo.

1 Dohrn, A., "Der Ursprung der Wirbeltiera u. des Prinzip des Funkionswechsels" (Leipzig, 1875).

${ }^{2}$ Naef, A., Pub. Staz. Zool. Napoli, 7, No. 12 (1925).

\section{Shadow Area of Convex Bodies}

Vouk $^{1}$, in a letter in Nature, gave a proof of Cauchy's theorem that the average area of projection of a convex body on a plane equals one-quarter the surface area of the body. The following less formal version of the proof may appeal more to nonmathematicians.

The projected area of a sphere equals the area of

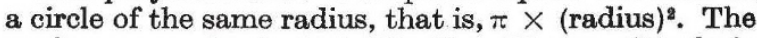
surface area is $4 \pi \times$ (radius) $^{2}$. Hence, Cauchy's result is true for a sphere. Because of the symmetry of a sphere, the result must be true of each infinitesimal element of the sphere's surface, that is, any infinitesimal element of area considered in all its possible orientations has an average projected area equal to one quarter of its own area. Now the surface of any convex body consists of a number of such infinitesimal areas; hence by adding the separate contributions from each we obtain Cauchy's theorem. As pointed out by Vouk ${ }^{1}$, if the assumption of convexity were not made, the above value of shadow area will be too large, because the contributions of certain surface elements in certain orientations will be nullified by obscuration.

\author{
Mullard Radio Valve Co., Ltd. \\ New Road, \\ Mitcham Junction, \\ Surrey. \\ Sept. 3.
}

Vouk, V., Nature, 162, 331 (1948).

BERNARD MELTZER

\section{Bilateral Asymmetry shown by the Meta- chronal Waves in Protochordate Gill Slits}

BECAUSE of delay in correcting and returning proofs, the letter under this title in Nature of January 22 , p. 137 , contains an error in the last paragraph. The larvæ of Enteropneusta rotate in an anti-clock. wise direction viewed from the animal pole, not a clockwise one. To judge from the literature there cited and from a later reference to the subject by van Wijhe1, the hatching larvæ of Amphioxus ${ }^{2}$, which are remarkably similar in general appearance to Saccoglossus larvæ, rotate consistently in the same direction and swim in a similar manner.

E. W. KNIGHT JoNes

Ministry of Agriculture and Fisheries,

Burnham-on-Crouch, Essex.

Jan. 24.

${ }^{1}$ Wijhe, J. W. van, Proc. Akad. van Wetensch., Sect. Sci., 30 (2), 991 (1927).

${ }^{2}$ Hatschek, B., Arb. Zool. Univ. Wien, 4, 1 (1881). 